\title{
Perbandingan EQ-5D-5L dan SF-6D Untuk Mengukur Index Utility Kesehatan Pada Populasi Umum di Yogyakarta
}

\author{
Comparison of EQ-5D-5L and SF-6D for Measuring Health Utility Index in the General Population
}

\author{
Tri Murti Andayani ${ }^{1^{*}}$, Dwi Endarti ${ }^{2}$, Susi Ari Kristina², Anindya Rahmawati ${ }^{3}$ \\ 1. Fakultas Departemen Farmakologi dan Farmasi Klinik, Fakultas Farmasi, Universitas Gajah Mada \\ 2. Departemen Farmasetika, Fakultas Farmasi, Universitas Gajah Mada \\ 3. Program Pascasarjana Farmasi Klinik, Universitas Gajah Mada
}

Submitted: 11-09-2019 Revised: 12-11-2019

Korespondensi : Tri Murti Andayani : Email : trimurtia@ugm.ac.id

Accepted: 11-03-2020

\begin{abstract}
ABSTRAK
EuroQuality of life-5 dimension 5 level (EQ-5D-5L) dan Short Form-6 Dimension (SF-6D) merupakan instrumen generik yang paling banyak digunakan untuk menilai utilitas sebagai parameter outcome pada studi farmakoekonomi. Perbedaan instrumen akan memberikan nilai utilitas yang berbeda dan mempengaruhi pengambilan keputusan. Tujuan penelitian ini adalah untuk membandingkan skore index utilitas yang diukur menggunakan EQ-5D-5L dan SF-6D pada populasi umum. Penelitian dilakukan dengan pendekatan observasional menggunakan rancangan cross sectional pada populasi umum di wilayah kota Yogyakarta. Kuesioner EQ-5D-5L dan SF-6D diberikan kepada 470 responden untuk mengukur skore indeks utilitas. Perbedaan skore indeks utilitas berdasarkan karakteristik demografi diuji menggunakan Mann Whitney dan Kruskal Wallis, sedangkan korelasi antar domain EQ-5D dan SF-6D dengan skore utilitas digunakan Pearson Correlation. Limits of agreement digambarkan dengan Bland and Altman Plot. Hasil penelitian menunjukkan skore utilitas yang diukur menggunakan EQ-5D-5L, EQ-VAS, dan SF-6D masing-masing 0,944(SD=0.093), 0,829(SD=0,089), dan 0,915(SD=0,081). EQ-5D-5L dan EQ-VAS dapat membedakan nilai utilitas berdasarkan usia. Terdapat korelasi yang kuat (>0.700) antara domain mobilitas dan nyeri dengan EQ-5D-5L utility index, serta domain fungsi fisik dan nyeri dengan SF-6D utility index. Ceilling effect pada EQ-5D-5L (59\%) lebih besar dibandingkan pada SF-6D (22,4\%). Bland and Altman plot menunjukkan perbedaan skore utilitas antara EQ-5D-5L dan SF-6D, SF-6D dan EQ-VAS, dan EQ-5D-5L dan VAS, masing-masing berada pada limit of agreement 92,98\%, 96,38\%, dan 95,74\%. EQ-5D-5L dapat membedakan skore utilitas berdasarkan usia, namun menunjukkan ceiling effect yang lebih tinggi. Baik EQ-5D-5L maupun SF-6D menunjukkan korelasi yang kuat antara domain mobilitas/fungsi fisik dan nyeri dengan skore utilitas.
\end{abstract}

Kata kunci: indeks utilitas; EQ-5D-5L; SF-6D; populasi umum

\begin{abstract}
The EuroQuality of life-5 dimension 5 level (EQ-5D-5L) and Short Form-6 Dimension (SF-6D) are the most widely used generic instruments for assessing utility as an outcome parameter in pharmacoeconomic studies. Different instruments cause different utility values and influence the decision making. The purpose of this study was to compare the utility score index measured using EuroQuality of life-5 dimension 5 levels (EQ-5D-5L) and Short Form-6 Dimension (SF-6D) in general population. The study was conducted cross sectional design in general population in the Yogyakarta. EQ-5D-5L and SF-6D questionnaires were given to 470 respondents to measure the utility score index. Differences of utility index scores based on demographic characteristics were analyzed using Mann Whitney and Kruskal Wallis test, while correlations between EQ-5D and SF-6D domains with utility scores were analyzed using Pearson Correlation. Limits of agreement were described by Bland and Altman Plot. The results of the study showed the utility scores measured using EQ-5D-5L, EQ-VAS, and SF-6D were 0.944 (SD = 0.093), $0.829(\mathrm{SD}=0.089)$ and $0.915(\mathrm{SD}=0.081)$ respectively. EQ-5D-5L and EQ-VAS can distinguish utility values based on age. There is a strong correlation ( $>0.700$ ) between the domain of mobility and pain with the EQ-5D-5L utility index, and the domain of physical function and pain with the SF-6D utility index. Ceiling effect of EQ-5D-5L (59\%) is greater than SF-6D (22.4\%). The Bland and Altman plot shows the difference in utility scores of EQ-5D-5L with SF-6D, SF-6D with EQ-VAS, and EQ-5D-5L with VAS, respectively at the limit of agreement 92.98\%, $96,38 \%$, and 95.74\%. EQ-5D-5L can distinguish utility scores based on age,
\end{abstract}


but showed higher ceiling effect. Both EQ-5D-5L and SF-6D showed a strong correlation between the domain of mobility (physical function) and pain with the utility score.

Keywords: utility index; EQ-5D-5L; SF-6D; the general population

\section{PENDAHULUAN}

Indonesia telah melaksanakan program Jaminan Kesehatan Nasional sejak tahun 2014. Tujuan dari program tersebut adalah untuk menjamin terpenuhinya kebutuhan dasar hidup yang layak berupa manfaat pemeliharaan dan perlindungan kesehatan bagi tiap warga negara Indonesia. Kemajuan teknologi kedokteran yang semakin canggih dan mahal menyerap dana sangat besar, sementara dana yang tersedia amat terbatas ${ }^{1}$. Oleh karena itu perlu dilakukan pengkajian teknologi kesehatan, diantaranya dengan costutility analysis (CUA). CUA merupakan metode analisis ekonomi kesehatan yang dilakukan dengan membandingkan biaya dan outcome dari intervensi kesehatan, sebagai pertimbangan untuk menentukan apakah teknologi kesehatan tersebut dapat masuk dalam paket benefit ${ }^{2}$.

Instrumen untuk menilai parameter outcome dalam indeks kesehatan tunggal (indeks utilitas) semakin banyak digunakan. Instrumen yang sudah banyak digunakan diantaranya adalah EQ-5D dan SF-6D². Instrumen tersebut berbeda dalam algoritme skoreing dan sistim deskriptif dari keadaan kesehatan (health state), sehingga hasil skore indeks utilitas dapat bervariasi berdasarkan instrumen yang dipilih. Selain itu, beberapa bukti menunjukkan terdapat perbedaan level of agreement antara kedua instrument tersebut terhadap rentang status kesehatan dari suatu penyakit, sehingga potensial menyebabkan perbedaan estimasi dari nilai indeks utilitas ${ }^{4}$. Sebagai contoh, pada pasien gagal jantung, EQ-5D dan SF-6D menunjukkan nilai yang berbeda berdasarkan keparahan penyakit, yaitu pada domain kapasitas fungsional. EQ5D menunjukkan skore yang lebih tinggi dibandingkan SF-6D pada kelompok pasien yang kurang parah dan skore lebih rendah pada kelompok yang lebih parah ${ }^{5}$. Pada pasien rheumatoid arthritis yang lebih parah, median skore EQ-5D menunjukkan nilai yang lebih rendah dibandingkan median skore SF-6D'6.
Dimensi pada SF-6D lebih luas, yaitu adanya tambahan dimensi vitalitas dan fungsi sosial dibandingkan EQ-5D, hal ini menyebabkan SF-6D lebih sensitif pada keadaan kesehatan yang mempengaruhi dimensi tersebut. Selain itu level dari dimensi SF-6D lebih banyak, dan adanya floor effect pada SF-6D dan ceiling effect pada EQ-5D, menyebabkan kedua instrument ini berbeda dalam mendiskripsikan keadaan kesehatan yang paling baik (full health) dan paling buruk (worse health). Sebagai akibatnya EQ-5D lebih sensitif pada kelompok pasien dengan keadaan kesehatan yang parah, dan kurang sensitif pada kelompok pasien dengan keadaan kesehatan lebih ringan. Value set EQ5D-5L sudah dikembangkan di banyak negara dengan metode time trade-off dan yang sudah dipublikasikan dari 18 negara, diantaranya Canada, USA, The Netherlands, China, England, Germany, Indonesia, dan beberapa negara lain. Value set SF-6D sudah dikembangkan pertama kali menggunakan standart gamble di United Kingdom, Hong Kong, Japan, Portugal, dan Brazil ${ }^{4}$. Namun demikian value set untuk populasi Indonesia belum dikembangkan. Perbedaan instrument dapat menyebabkan outcome evaluasi ekonomi yang berbeda, yang akan mempengaruhi keputusan pelayanan kesehatan. Tujuan dari penelitian ini adalah untuk membandingkan EQ-5D-5L dan SF-6D untuk mengukur indeks utilitas pada populasi umum di Indonesia, sehingga dapat digunakan sebagai data pendukung dalam memilih instrument yang lebih tepat untuk menilai QALYs sebagai outcome pada evaluasi ekonomi.

\section{METODE \\ Sampel dan Pengumpulan data}

Penelitian dilakukan dengan rancangan cross sectional pada populasi umum di wilayah kota Yogyakarta. Kriteria inklusi adalah responden dengan usia lebih dari 18 tahun, bersedia terlibat dalam penelitian, mengisi 
kuesioner secara lengkap, dan berdomisili di wilayah kota Yogyakarta. Kepada 470 responden yang bertempat tinggal di wilayah kota Yogyakarta, dengan berbagai karakteristik demografi diberikan kuesioner EQ-5D-5L dan SF-6D, serta pertanyaan berkaitan dengan sosio-demografi (jenis kelamin, usia, tingkat pendidikan, status perkawinan, dan pendapatan). Kuesioner diisi sendiri oleh responden, namun jika responden tidak bersedia mengisi sendiri, dibantu oleh peneliti. Partisipan yang bersedia diikutkan dalam penelitian memberikan informed consent dan diberikan souvenir sebagai kompensasi keterlibatan dalam penelitian. Penelitian ini sudah mendapatkan persetujuan etik dari Komite Etik Fakultas Kedokteran dengan nomor KE/FK/0930/EC/2018.

\section{Penilaian Health-Related Quality of Life (HRQOL)}

HRQoL responden dinilai menggunakan instrument EQ-5D-5L dan SF-6D versi Indonesia. Penilaian indeks SF-6D dilakukan menggunakan program excel yang dikembangkan oleh University of Sheffield. Estimasi skore menggunakan preferensi parametrik yang diperoleh dari sampel populasi umum di Inggris menggunakan teknik penilaian standar gamble karena belum ada algoritme skoreing indeks SF-6D menggunakan populasi Indonesia7. SF-6D terdiri dari 6 dimensi dengan skore/level yang berbeda pada tiap dimensi, meliputi dimensi fungsi fisik dengan 6 level, dimensi keterbatasan peran 4 level, fungsi sosial 5 level, rasa sakit 6 level, kesehatan mental 5 level, dan vitalitas 5 level. Skore jawaban responden selanjutnya diolah menggunakan program excel untuk mendapatkan nilai index utilitas SF-6D. Nilai 1 menunjukkan keadaan kesehatan yang paling baik dan nilai 0,29 menunjukkan keadaan kesehatan yang paling buruk $^{8}$.

Indeks EQ-5D-5L dinilai menggunakan set penilaian yang dikembangkan oleh Purba et al. untuk populasi Indonesia 9 . EQ-5D-5L terdiri dari 5 dimensi dengan 5 level jawaban, mulai dari tidak ada permasalahan sampai dengan permasalahan yang sangat berat, meliputi dimensi kemampuan berjalan, perawatan diri, kegiatan yang biasa dilakukan, rasa nyeri atau tidak nyaman, dan rasa cemas atau depresi ${ }^{10}$. Rentang nilai indeks utilitas EQ-5D-5L antara 0 (keadaan kesehatan yang sangat buruk yang setara dengan meninggal) sampai dengan 1 (keadaan kesehatan yang sangat baik) ${ }^{9}$. Bagian lain dari EQ-5D-5L adalah visual analog scale (EQ-VAS), yang dapat digunakan untuk menilai status kesehatan dari responden dengan menggunakan skala $100-\mathrm{mm}$ dengan range skore dari 0 (keadaan kesehatan aling buruk) sampai 100 (keadaan kesehatan paling baik). Penilaian EQ-VAS didasarkan pada jawaban responden terkait dengan keadaan kesehatannya dengan rentang 0 (kesehatan paling buruk atau setara dengan meninggal) sampai dengan 100 (keadaan kesehatan paling baik).

\section{Analisis statistik}

Karakteristik demografi dan distribusi item digambarkan dalam jumlah dan persentase. Variabel kontinyu, termasuk skore utilitas dipresentasikan dalam rata-rata dan standar deviasi. Dilakukan perbandingan ceiling effect antara EQ-5D-5L dan SF-6D dengan menghitung persentase responden dengan skore jawaban 11111 pada EQ-5D-5L dan 111111 pada SF-6D. Spearman correlation digunakan untuk mengevaluasi korelasi antar domain dan index skore sebagai berikut : tidak berhubungan $<0,200$, berkorelasi rendah 0,200 sampai 0,300, sedang 0,31 sampai 0,500, kuat > 0.500 , sangat kuat $>0,700 .{ }^{6}$ Level of agreement EQ-5D-5L dan SF-6D dianalisa menggunakan Bland-Altman plot. Rata-rata dari 2 pengukuran diplotkan pada $\mathrm{x}$-axis dan ratarata perbedaan antara 2 pengukuran diplotkan pada y-axis. Good agreement antara 2 pengukuran jika perbedaan rata-rata mendekati 0 dan $95 \%$ perbedaan berada pada 2 standar deviasi dari mean difference. Convergent validity SF-6D dievaluasi dengan membandingkan instrumen tersebut dengan kuesioner EQ-5D-5L, karena instrumen tersebut sudah banyak digunakan 
Tabel I. Karakteristik responden di wilayah Kota Yogyakarta $(n=470)$

\begin{tabular}{lcc}
\hline \multicolumn{1}{c}{ Karakteristik } & n & \% \\
\hline Usia (tahun) & & \\
$\quad$ Rata-rata \pm SD & $43 \pm 16$ & 52,6 \\
$\quad<45$ & 247 & 28,9 \\
$45-59$ & 136 & 18,5 \\
$\quad \geq 60$ & 87 & \\
Jenis Kelamin & & 70,2 \\
$\quad$ Perempuan & 330 & 29,8 \\
$\quad$ Laki-laki & 140 & \\
Tingkat Pendidikan & & 18,5 \\
$\quad$ Sekolah dasar & 87 & 20,9 \\
$\quad$ Sekolah Menengah & 98 & 45,5 \\
$\quad$ Sekolah Tingkat Atas & 214 & 15,1 \\
$\quad$ Akademi atau sarjana & 71 & \\
Status pekerjaan & & 41,3 \\
Bekerja & 194, & 48,1 \\
Tidak Bekerja & 226 & 10,6 \\
Lain-lain & 50 & \\
Penghasilan setiap bulan & & 47,4 \\
1.000.000,00 rupiah & 223 & 41,5 \\
1.000.000,00 - 3.000.000,00 rupiah & 195 & 11,1 \\
$\quad$ 3.000.000,00 rupiah & 52 & 16,2 \\
Status Pernikahan & & 73 \\
Belum menikah & 76 & 10,9 \\
Menikah & 343 & \\
Janda/Duda & 51 & \\
\hline
\end{tabular}

di Indonesia dan sudah tersedia value set untuk populasi Indonesia. Skore EQ-5D-5L diantara -0.865 (kesehatan paling buruk atau setara dengan meninggal) dan 100 (kesehatan paling baik). ${ }^{9}$ Known group validity menilai sejauh mana EQ-5D dan SF-6D dapat membedakan perbedaan karakteristik pasien dan keadaan klinik pasien. Pada penelitian ini, known group validity dinilai dengan membandingkan nilai rata-rata skore utilitas berdasarkan usia, jenis kelamin, tingkat pendidikan, pekerjaan, dan penghasilan.

\section{HASIL DAN PEMBAHASAN}

Kuesioner SF-6D dan EQ-5D merupakan kuesioner generik untuk mengukur health-related quality of life (HRQoL) dan sudah banyak digunakan untuk survei pada populasi, praktek klinik, maupun uji klinik $^{11}$. EQ-5D-5L dan SF-6D dapat digunakan dalam evaluasi ekonomi untuk estimasi preferensi indeks tunggal dari status kesehatan. SF-6D terdiri 6 dimensi multi-level, yang menggambarkan status kesehatan dari seleksi item pertanyaan dalam SF-36. SF-6D mendeskripsikan 18.000 status kesehatan secara umum, dapat digunakan untuk menilai Quality-Adjusted Life Years (QALYs) yang selanjutnya sebagai parameter outcome dalam cost-utility analysis ${ }^{7}$.

Hasil penelitian pada 470 responden di wilayah Yogyakarta menunjukkan rata-rata usia responden $43 \quad(\mathrm{SD}=16)$ tahun, usia terbanyak kurang dari 45 tahun (52,6\%), mayoritas dengan jenis kelamin perempuan (70,2\%) dengan tingkat pendidikan sekolah tingkat atas $(45,5 \%)$ (Tabel I). Hasil penelitian menunjukkan skore utility yang diukur menggunakan EQ-5D-5L, EQ-VAS, masing-masing 0,944 (SD=0.093) dan 0,829 
Tabel II. Korelasi antar dimensi pada instrumen EQ-5D-5L

\begin{tabular}{|c|c|c|c|c|c|c|c|}
\hline & $\begin{array}{c}\text { Kemampuan } \\
\text { berjalan } \\
\text { EQ5D }\end{array}$ & $\begin{array}{l}\text { Perawatan } \\
\text { diri EQ5D }\end{array}$ & $\begin{array}{c}\text { Kegiatan } \\
\text { yang biasa } \\
\text { dilakukan } \\
\text { EQ5D }\end{array}$ & $\begin{array}{c}\text { Rasa } \\
\text { nyeri/tidak } \\
\text { nyaman } \\
\text { EQ5D }\end{array}$ & $\begin{array}{c}\text { Rasa } \\
\text { cemas/ } \\
\text { depresi } \\
\text { EQ5D }\end{array}$ & $\begin{array}{c}\text { VAS } \\
\text { EQ5D }\end{array}$ & $\begin{array}{c}\text { Index } \\
\text { utilitas } \\
\text { EQ5D }\end{array}$ \\
\hline $\begin{array}{l}\text { Kemampuan } \\
\text { berjalan } \\
\text { EQ5D }\end{array}$ & 1,000 & & & & & & \\
\hline $\begin{array}{l}\text { Perawatan } \\
\text { diri EQ5D }\end{array}$ & $0,127^{* *}$ & 1,000 & & & & & \\
\hline $\begin{array}{l}\text { Kegiatan } \\
\text { yang biasa } \\
\text { dilakukan } \\
\text { EQ5D }\end{array}$ & $0,296^{* *}$ & $0,542^{* *}$ & 1,000 & & & & \\
\hline $\begin{array}{l}\text { Rasa } \\
\text { nyeri/tidak } \\
\text { nyaman } \\
\text { EQ5D }\end{array}$ & $0,300^{* *}$ & 0,062 & $0,234^{* *}$ & 1,000 & & & \\
\hline $\begin{array}{l}\text { Rasa } \\
\text { cemas/depre } \\
\text { si EQ5D }\end{array}$ & $0,172^{* *}$ & 0,018 & $0,203^{* *}$ & $0,310^{* *}$ & 1,000 & & \\
\hline VAS EQ5D & $-0.208^{* *}$ & $-0,113^{*}$ & $-0,197^{* *}$ & $-0,322^{* *}$ & $-0,245^{* *}$ & 1.000 & \\
\hline $\begin{array}{l}\text { Index } \\
\text { utilitas } \\
\text { EQ5D }\end{array}$ & $-0,700^{* *}$ & $-0,328^{* *}$ & $-0,584^{* *}$ & $-0,712^{* *}$ & $-0,596^{* *}$ & $0.364^{* *}$ & 1.000 \\
\hline
\end{tabular}

${ }^{*}$ Correlation is significant at the 0.05 level (2-tailed); ${ }^{* *}$ Correlation is significant at the 0.01 level (2-tailed)

$(\mathrm{SD}=0,089)$. Hasil penelitian ini berbeda dengan penelitian di beberapa negara, EQ-5D utility index pada populasi di Vietnam 0.91 (SD $=0.15)$ dan EQ-VAS $87.4(\mathrm{SD}=14.3)$, populasi di Australia selatan 0.91 (95\% CI $0.9,0.91)$ dan EQ-VAS $78.55 \quad(95 \%$ CI $77.95, \quad 79.15)$, sedangkan di Malaysia rata-rata skoree EQ-5D adalah $0.930(\mathrm{SD}=0.13)$ [4]. Sedangkan SF-6D utility index pada penelitian ini adalah 0,915 $(\mathrm{SD}=0,081)$, berbeda bermakna dengan EQ-5D utility index. Hasil penelitian ini konsisten dengan penelitian sebelumnya, bahwa dari beberapa penelitian yang membandingkan EQ-5D dan SF-6D pada populasi berbeda, secara umum terdapat perbedaan skore utilitas dari kedua instrumen tersebut. EQ-5D cenderung menunjukkan skore lebih tinggi dibandingkan SF-6D pada populasi sehat atau penyakit ringan, namun menunjukkan nilai yang lebih rendah pada penyakit yang berat. Perbedaan nilai utilitas ini disebabkan beberapa hal antara lain sistem deskripsi status kesehatan dari kuesioner yang berbeda, aspek yang diukur dengan SF-6D juga lebih luas dibandingkan EQ-5D, dan algoritme skoreing indeks utilitas yang berbeda. Skoreing EQ-5D-5L menggunakan value set dari populasi umum di Indonesia, dimana untuk mendapatkan 3125 EQ-5D-5L health states, dilakukan interview pada 1054 responden dengan metode time-trade off. Sedangkan skoreing indeks utilitas SF-6D diperkirakan menggunakan preferensi parametrik yang diperoleh dari general population di United Kingdom menggunakan teknik standar gamble ${ }^{12,13,14}$.

Validitas konstruk internal dilakukan dengan uji Korelasi Spearman antar dimensi 
Tabel III. Korelasi antar dimensi pada instrumen SF-6D

\begin{tabular}{lccccccc}
\hline & $\begin{array}{c}\text { Fungsi } \\
\text { fisik } \\
\text { SF6D }\end{array}$ & $\begin{array}{c}\text { Keterbatasan } \\
\text { peran SF6D }\end{array}$ & $\begin{array}{c}\text { Fungsi } \\
\text { sosial } \\
\text { SF6D }\end{array}$ & $\begin{array}{c}\text { Rasa } \\
\text { sakit } \\
\text { SF6D }\end{array}$ & $\begin{array}{c}\text { Kesehatan } \\
\text { mental } \\
\text { SF6D }\end{array}$ & $\begin{array}{c}\text { Vitalitas } \\
\text { SF6D }\end{array}$ & $\begin{array}{c}\text { Index } \\
\text { utilitas } \\
\text { SF6D }\end{array}$ \\
\hline $\begin{array}{l}\text { Fungsi fisik } \\
\text { SF6D }\end{array}$ & $\mathbf{1 , 0 0 0}$ & & & & & & \\
$\begin{array}{l}\text { Keterbatasan } \\
\text { peran SF6D }\end{array}$ & $0,402^{* *}$ & $\mathbf{1 , 0 0 0}$ & & & & \\
$\begin{array}{l}\text { Fungsi sosial } \\
\text { SF6D }\end{array}$ & $0,378^{* *}$ & $0,368^{* *}$ & $\mathbf{1 , 0 0 0}$ & & & \\
$\begin{array}{l}\text { Rasa sakit } \\
\text { SF6D }\end{array}$ & $0,408^{* *}$ & $0,429^{* *}$ & $0,365^{* *}$ & $\mathbf{1 , 0 0 0}$ & & \\
$\begin{array}{l}\text { Kesehatan } \\
\text { mental SF6D }\end{array}$ & $0,170^{* *}$ & $0,203^{* *}$ & 0,069 & $0,118^{*}$ & $\mathbf{1 , 0 0 0}$ & & \\
$\begin{array}{l}\text { Vitalitas SF6D } \\
\text { Index utilitas }\end{array}$ & 0,029 & $0,098^{*}$ & $0,091^{*}$ & $0,130^{* *}$ & 0,064 & $\mathbf{1 , 0 0 0}$ & \\
SF6D & $-0,708^{* *}$ & $-0,637^{* *}$ & $-0,606^{* *}$ & $-0,735^{* *}$ & $-0,487^{* *}$ & $-0,203^{* *}$ & $\mathbf{1 , 0 0 0}$ \\
\hline
\end{tabular}

${ }^{*}$ Correlation is significant at the 0.05 level (2-tailed); ${ }^{* *}$ Correlation is significant at the 0.01 level (2-tailed)

pada kuesioner SF-6D. Validitas konstruk internal dari EQ-5D-5L menunjukkan korelasi yang sangat kuat pada dimensi kemampuan berjalan $(\mathrm{r}=-0,700)$ dan rasa nyeri/tidak nyaman ( $\mathrm{r}=-0.712)$ dengan index utilitas EQ5D-5L, sedangkan pada dimensi kegiatan yang biasa dilakukan dan rasa cemas/depresi menunjukkan korelasi yang kuat, demikian juga antara dimensi kegiatan yang biasa dilakukan dengan perawatan diri (Tabel II). Sejalan dengan instrumen EQ-5D-5L, dimensi pada SF-6D yang menunjukkan korelasi yang sangat kuat dengan indeks utilitas SF-6D adalah fungsi fisik dan rasa sakit, sedangkan keterbatasan peran dan fungsi sosial menunjukkan korelasi kuat (Tabel III). Validitas konvergen menunjukkan terdapat korelasi yang kuat antara indeks utilitas EQ5D-5L dan SF-6D, namun korelasi antara dimensi kedua instrumen menunjukkan korelasi yang lemah dan sedang (Tabel IV). Hal ini disebabkan adanya perbedaan dimensi yang diukur, dimana aspek yang diukur pada SF-6D lebih luas dengan skala pengukuran yang berbeda. Selain itu penilaian health utility index EQ-5D sudah menggunakan value set dari populasi di Indonesia, sedangkan estimasi health utility index SF-6D menggunakan algoritme dari United Kingdom. Known group validity menunjukkan EQ-VAS dan EQ-5D-5L dapat membedakan pengaruh usia terhadap nilai utilitas, dan tingkat pendidikan pada EQ-VAS. Namun demikian tidak ada perbedaan yang bermakna nilai utility yang diukur dengan SF-6D berdasarkan sosiodemografi responden.

Pada penelitian ini, validitas konten dinilai secara deskriptif dengan ceiling effect (Tabel V). Ceiling effect dinilai dari persentase responden dengan ceiling level, yaitu ekuivalen dengan 10\% responden dengan nilai skala paling baik. Dari 470 responden, 59,0\% melaporkan tidak ada permasalahan pada semua dimensi EQ-5D dan 22,4\% responden tidak ada keterbatasan pada semua dimensi SF-6D. Hasil penelitian menunjukkan ceiling effect pada EQ-5D sangat tinggi (59,0\%), hal ini konsisten dengan penelitian sebelumnya, ceiling effect pada EQ-5D di Spanish $62,5 \%$ dan lebih tinggi dari Australia (42,8\%), UK (47,6\%), Germany $(47,5 \%)$, Uruguay $(44,0 \%)$, dan Polandia $(38,5 \%)^{3,15}$. Penelitian sebelumnya menunjukkan bahwa EQ-5D lebih sesuai untuk mengukur kesehatan dengan banyak 
Tri Murti Andayani, et al

Tabel IV. Korelasi antar dimensi dari instrumen SF-6D, EQ-5D-5L dan EQ-VAS

\begin{tabular}{|c|c|c|c|c|c|c|c|}
\hline & $\begin{array}{c}\text { Kemampuan } \\
\text { berjalan } \\
\text { EQ5D }\end{array}$ & $\begin{array}{c}\text { Perawatan } \\
\text { diri EQ5D }\end{array}$ & $\begin{array}{c}\text { Kegiatan } \\
\text { yang biasa } \\
\text { dilakukan } \\
\text { EQ5D }\end{array}$ & $\begin{array}{c}\text { Rasa } \\
\text { nyeri/tidak } \\
\text { nyaman } \\
\text { EQ5D }\end{array}$ & $\begin{array}{c}\text { Rasa } \\
\text { cemas/ } \\
\text { depresi } \\
\text { EQ5D }\end{array}$ & $\begin{array}{c}\text { VAS } \\
\text { EQ5D }\end{array}$ & $\begin{array}{c}\text { Index } \\
\text { utilitas } \\
\text { EQ5D }\end{array}$ \\
\hline $\begin{array}{l}\text { Fungsi fisik } \\
\text { SF6D }\end{array}$ & $0,251^{\text {** }}$ & $0,296^{* *}$ & $0,405^{* *}$ & $0,268^{* *}$ & $0,118^{* *}$ & $-0,241^{* *}$ & $-0,385^{* *}$ \\
\hline $\begin{array}{l}\text { Keterbatasan } \\
\text { peran SF6D }\end{array}$ & $0,309^{* *}$ & $0,246^{* *}$ & $0,359^{* *}$ & $0,247^{* *}$ & $0,352^{* *}$ & $-0,267^{* *}$ & $-0,463^{* *}$ \\
\hline $\begin{array}{l}\text { Fungsi sosial } \\
\text { SF6D }\end{array}$ & $0,277^{* *}$ & 0,074 & $0,260^{* *}$ & $0,210^{* *}$ & $0,108^{* *}$ & $-0,101^{* *}$ & $-0,325$ \\
\hline $\begin{array}{l}\text { Rasa sakit } \\
\text { SF6D }\end{array}$ & $0,301^{* *}$ & $0,101^{*}$ & $0,225^{* *}$ & $0,433^{* *}$ & $0,273^{* *}$ & $-0,224^{* *}$ & $-0,456^{* *}$ \\
\hline $\begin{array}{l}\text { Kesehatan } \\
\text { mental SF6D }\end{array}$ & 0,071 & 0,015 & $-0,031$ & $0,110^{*}$ & $0,205^{* *}$ & $-0,159^{* *}$ & $-0,142^{* *}$ \\
\hline $\begin{array}{l}\text { Vitalitas } \\
\text { SF6D }\end{array}$ & 0,108 & 0,016 & $0,095^{*}$ & 0,031 & $0,087^{*}$ & $-0,088$ & $-0,097$ \\
\hline $\begin{array}{l}\text { Index utilitas } \\
\text { SF6D }\end{array}$ & $-0,312^{* *}$ & $-0,175^{* *}$ & $-0,344^{* *}$ & $-0.392^{* *}$ & $-0,335^{* *}$ & $0,292^{* *}$ & $0,515^{* *}$ \\
\hline
\end{tabular}

${ }^{*}$ Correlation is significant at the 0.05 level (2-tailed); ${ }^{* *}$ Correlation is significant at the 0.01 level (2-tailed)

Tabel V. Perbandingan Ceiling Effect EQ-5D-5L dengan SF-6D

\begin{tabular}{cccccc}
\hline & EQ-5D-5L & & & SF-6D & \\
\hline Health state & Jumlah & \% & Health state & Jumlah & $\%$ \\
\hline 11111 & 277 & 59,0 & 111111 & 105 & 22,4 \\
11112 & 29 & 6,1 & 111112 & 2 & 0,4 \\
11113 & 3 & 0,6 & 111113 & 1 & 0,2 \\
11121 & 58 & 12,3 & 111121 & 49 & 10,5 \\
11122 & 13 & 2,8 & 111122 & 4 & 0,8 \\
11123 & 3 & 0,6 & 111123 & 1 & 0,2 \\
11131 & 8 & 1,6 & 111131 & 8 & 1,6 \\
11132 & 2 & 0,4 & 111132 & 36 & 7,7 \\
11134 & 1 & 0,2 & 111141 & 1 & 0,2 \\
11141 & 1 & 0,2 & 111211 & 46 & 9,7 \\
\hline
\end{tabular}

morbiditas, sedangkan SF-6D mempunyai keterbatasan jika digunakan untuk mengukur status kesehatan yang parah. Secara umum, kedua alat ukur tersebut tidak ekivalen, validitas dan perbandingan responsivitas dari EQ-5D dan SF-6D berbeda tergantung dari populasi yang dinilai.

Bland and Altman plot (Gambar 1) menunjukkan limit of agreement EQ-5D-5L dengan SF-6D 0.340 dan SF-6D dengan VAS 0,400. Gambar 1a menunjukkan sekitar 92,98\% perbedaan skore utilitas antara EQ-5D-5L dan SF-6D berada pada limit of agreement, namun $4,47 \%$ perbedaan skore utilitas berada di bawah batas terendah (garis hijau) dari limit of agreement. Sekitar 96,38\% perbedaan skore utilitas antara SF-6D dan EQ-VAS berada pada limit of agreement, dimana $2,34 \%$ perbedaan 


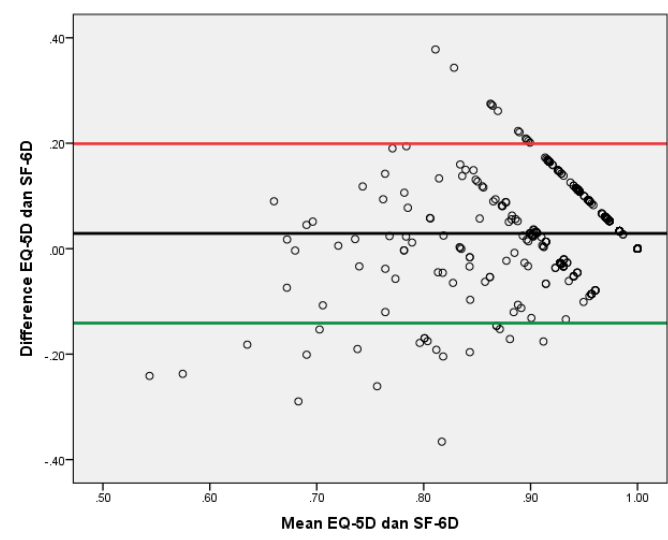

(a)

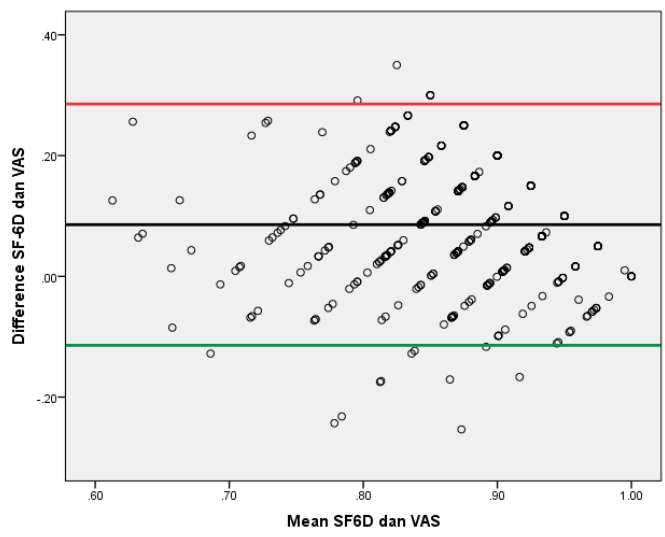

(b)

\section{Gambar 1. Bland and Altman Plot EQ-5D-5L dengan SF-6D (a) dan SF-6D dengan EQ-VAS (b).}

skore utilitas di bawah batas terendah limit of agreement (Gambar 1B). Bland and Altman plot juga menunjukkan pola hubungan antara perbedaan dan rata-rata skore utilitas ${ }^{16}$. Dari gambar terlihat bahwa skore utilitas dari EQ5D-5L lebih rendah dibandingkan SF-6D pada responden dengan status kesehatan yang lebih rendah (Gambar 1A).

Instrumen EQ-5D-5L, EQ-VAS, maupun SF-6D dapat membedakan nilai utilitas berdasarkan sosiodemografi, namun demikian perbedaan yang signifikan ditunjukkan oleh instrumen EQ-5D-5L dalam membedakan skore utilitas berdasarkan usia (Tabel VI). Penelitian sebelumnya menunjukkan SF-6D lebih efisien dalam membedakan perubahan kualitas hidup, namun demikian beberapa penelitian masih memilih menggunakan EQ-5D untuk membandingkan pre dan post intervensi pada praktek klinik. Chen et al melaporkan bahwa persentase data yang kurang tepat dengan menggunakan EQ-5D lebih rendah dibandingkan SF-6D baik pada baseline maupun post intervensi untuk menilai pengaruh intervensi pembedahan yang berbeda pada pasien dengan penyakit jantung koroner. Sedangkan penelitian lain menunjukkan SF-6D lebih tepat untuk menilai QALYs pada pasien dengan penyakit paru obstruksi kronis dibandingkan EQ-5D.
Dua instrument tidak dapat saling menggantikan, sehingga perlu hati-hati dalam memilih instrumen untuk menilai utilitas. ${ }^{12}$ Konsisten dengan hasil penelitian ini, dimana ceiling effect pada EQ-5D-5L lebih tinggi dibandingkan SF-6D dan Bland-Altman plot mengambarkan skoree utilitas dari EQ-5D lebih tinggi dibandingkan SF-6D pada populasi sehat atau penyakit ringan, namun menunjukkan nilai yang lebih rendah pada status kesehatan yang berat.

Keterbatasan penelitian ini adalah pertama, penelitian dilakukan menggunakan rancangan cross sectional, hanya dilakukan satu kali evaluasi terhadap kualitas hidup responden, sehingga tidak dapat mengevaluasi perubahan skore utilitas terhadap perubahan status kesehatan. Keterbatasan yang kedua, kurangnya variasi riwayat sakit responden, sehingga belum dapat menggambarkan skore utilitas berdasarkan keadaan kesehatan. Ketiga, metode skoreing utilitas menggunakan algoritma skoreing yang dikembangkan oleh University of Shiefield pada populasi di Inggris. Hal ini dapat menyebabkan nilai skore utilitas yang kurang sesuai dengan populasi di Indonesia. Untuk penelitian selanjutnya dapat dilakukan metode skoreing instrumen SF-6D berdasarkan populasi Indonesia. 
Tri Murti Andayani, et al

Tabel VI. Perbedaan Index utilitas EQ-5D-5L, EQ-5D-VAS, dan SF-6D berdasarkan sosiodemografi responden

\begin{tabular}{|c|c|c|c|c|c|c|}
\hline Karakteristik & $\begin{array}{l}\text { EQ-5D-5L } \\
\text { index }\end{array}$ & $\mathrm{p}$ & EQ-VAS & $\mathrm{p}$ & $\begin{array}{l}\text { SF-6D } \\
\text { index }\end{array}$ & $\mathrm{p}$ \\
\hline \multicolumn{7}{|l|}{ Usia } \\
\hline $17-44$ th & $0,946 \pm 0,093$ & \multirow[t]{3}{*}{0,048} & $0,839 \pm 0,091$ & \multirow[t]{3}{*}{0,000} & $0,920 \pm 0,076$ & \multirow[t]{3}{*}{0,069} \\
\hline $45-59$ th & $0,956 \pm 0,075$ & & $0,834 \pm 0,086$ & & $0,922 \pm 0,073$ & \\
\hline$>60$ th & $0,918 \pm 0,114$ & & $0,795 \pm 0,027$ & & $0,889 \pm 0,102$ & \\
\hline \multicolumn{7}{|l|}{ Jenis Kelamin } \\
\hline Perempuan & $0,945 \pm 0,093$ & \multirow[t]{2}{*}{0,367} & $0,830 \pm 0,091$ & \multirow[t]{2}{*}{0,554} & $0,911 \pm 0,083$ & \multirow[t]{2}{*}{0,248} \\
\hline Laki-laki & $0,941 \pm 0,095$ & & $0,827 \pm 0,085$ & & $0,922 \pm 0,077$ & \\
\hline \multicolumn{7}{|l|}{ Pendidikan } \\
\hline Sekolah dasar & $0,929 \pm 0,119$ & \multirow[t]{4}{*}{0,298} & $0,816 \pm 0,101$ & \multirow[t]{4}{*}{0,028} & $0,897 \pm 0,095$ & \multirow[t]{4}{*}{0,303} \\
\hline Sekolah menengah & $0,942 \pm 0,085$ & & $0,829 \pm 0,087$ & & $0,911 \pm 0,092$ & \\
\hline Sekolah tingkat atas & $0,945 \pm 0,092$ & & $0,826 \pm 0,084$ & & $0,921 \pm 0,069$ & \\
\hline Sarjana atau akademi & $0,963 \pm 0,067$ & & $0,853 \pm 0.090$ & & $0,922 \pm 0,079$ & \\
\hline \multicolumn{7}{|l|}{ Pekerjaan } \\
\hline Tidak bekerja & $0,944 \pm 0,096$ & \multirow[t]{3}{*}{0,280} & $0,826 \pm 0,093$ & \multirow[t]{3}{*}{0,711} & $0,908 \pm 0,085$ & \multirow[t]{3}{*}{0,563} \\
\hline Bekerja & $0,947 \pm 0,090$ & & $0,830 \pm 0,088$ & & $0,918 \pm 0,078$ & \\
\hline Lainnya & $0,928 \pm 0,094$ & & $0,838 \pm 0,076$ & & $0,922 \pm 0,077$ & \\
\hline \multicolumn{7}{|l|}{ Penghasilan } \\
\hline$<1$ juta & $0,938 \pm 0,100$ & \multirow[t]{3}{*}{0,726} & $0,823 \pm 0,088$ & \multirow[t]{3}{*}{0,160} & $0,911 \pm 0,086$ & \multirow[t]{3}{*}{0,852} \\
\hline $1-3$ juta & $0,946 \pm 0,093$ & & $0,831 \pm 0,091$ & & $0,917 \pm 0,077$ & \\
\hline$>3$ juta & $0,958 \pm 0,067$ & & $0,848 \pm 0,087$ & & $0,921 \pm 0,077$ & \\
\hline
\end{tabular}

\section{KESIMPULAN}

Hasil penelitian menunjukkan skoree utility yang diukur menggunakan EQ-5D-5L, EQ-VAS, dan SF-6D masing-masing 0,944(SD=0,093), 0,829(SD=0,089), dan $0,915(\mathrm{SD}=0,081)$. Terdapat korelasi yang kuat antara domain mobilitas dan nyeri dengan EQ-5D-5L utility index, serta domain fungsi fisik dan nyeri dengan SF-6D utility index. Ceilling effect pada EQ-5D-5L lebih besar dibandingkan pada SF-6D. Bland and Altman plot menunjukkan bahwa skoree utilitas dari EQ-5D-5L lebih rendah dibandingkan SF-6D pada responden dengan status kesehatan yang lebih berat.

\section{UCAPAN TERIMAKASIH}

Kementerian Riset, Teknologi, Dan Pendidikan Tinggi Republik Indonesia yang telah memberikan dana. Seluruh penulis tidak memiliki konflik interest terhadap instansi yang terlibat dalam penelitian.

\section{DAFTAR PUSTAKA}

1. PPJK. Buku Panduan Penilaian Teknologi Kesehatan Efektivitas Klinis Dan Evaluasi Ekonomi Pusat Pembiayaan Dan Jaminan Kesehatan. Jakarta: Kementerian Kesehatan RI Komite Penilaian Teknologi Kesehatan; 2017.

2. Andayani TM. Farmakoekonomi: Prinsip Dan Metodologi. Yogyakarta: Bursa Ilmu; 2013.

3. Nguyen LH, Tran BX, Hoang Le QN, Tran TT, Latkin CA. Quality of life profile of general Vietnamese population using EQ-5D-5L. Health Qual Life Outcomes. 2017;15(1).

4. Joore M, Brunenberg D, Nelemans P, Wouters E, Kuijpers P, Honig A, Willems D, de Leeuw P, Severens J, Boonen A. The Impact of Differences in 
EQ-5D and SF-6D Utility Scores on the Acceptability of Cost-Utility Ratios: Results across Five Trial-Based Cost-Utility Studies. Value Health. 2010;13(2):222-229.

5. Kontodimopoulos N, Pappa E, Papadopoulos AA, Tountas Y, Niakas D. Comparing SF-6D and EQ-5D utilities across groups differing in health status. Qual Life Res. 2009;18(1):87-97.

6. Salaffi F, Carotti M, Ciapetti A, Gasparini S, Grassi W. A comparison of utility measurement using EQ-5D and SF-6D preference-based generic instruments in patients with rheumatoid arthritis. Clin Exp Rheumatol. 2011;29(4):661-671.

7. Brazier JE, Roberts J. The Estimation of a Preference-Based Measure of Health From the SF-12: Med Care. 2004;42(9):851-859.

8. Ara R, Brazier J. Deriving an Algorithm to Convert the Eight Mean SF-36 Dimension Scores into a Mean EQ-5D Preference-Based Score from Published Studies (Where Patient Level Data Are Not Available). Value Health. 2008;11(7):1131-1143.

9. Purba FD, Hunfeld JAM, Iskandarsyah A,Fitriana TS, Sadarjoen SS, RamosGoni JM, Passchier J, Busschbach JJV. The Indonesian EQ-5D-5L Value Set. PharmacoEconomics. 2017;35(11):11531165.

10. Feng $\mathrm{Y}$, Devlin $\mathrm{N}$, Herdman $\mathrm{M}$. Assessing the health of the general population in England: how do the three- and five-level versions of EQ-5D compare? Health Qual Life Outcomes.
2015;13(1). doi:10.1186/s12955-015-03568

11. Islam N, Khan IH, Ferdous N, Rasker JJ. Translation, cultural adaptation and validation of the English "Short form SF 12v2" into Bengali in rheumatoid arthritis patients. Health Qual Life Outcomes. 2017;15(1).

12. Chen J, Wong CKH, McGhee SM, Pang PKP, Yu W-C. A Comparison between the EQ-5D and the SF-6D in Patients with Chronic Obstructive Pulmonary Disease (COPD). Courvoisier DS, ed. PLOS ONE. 2014;9(11):e112389.

13. McDonough CM, Grove MR, Tosteson TD, Lurie JD, Hilibrand AS, Tosteson ANA. Comparison of EQ-5D, HUI, and SF-36-derived societal health state values among spine patient outcomes research trial (SPORT) participants. Qual Life Res Int J Qual Life Asp Treat Care Rehabil. 2005;14(5):1321-1332.

14. Wu J, Han Y, Zhao F-L, Zhou J, Chen Z, Sun $\mathrm{H}$. Validation and comparison of EuroQoL-5 dimension (EQ-5D) and Short Form-6 dimension (SF-6D) among stable angina patients. Health Qual Life Outcomes. 2014;12(1).

15. Jin H, Wang B, Gao Q, Chao J, Wang S, Tian L, Liu P. Comparison between EQ5D and SF-6D Utility in Rural Residents of Jiangsu Province, China. Fielding R, ed. PLOS ONE. 2012;7(7):e41550.

16. Thaweethamcharoen $\mathrm{T}$, Noparatayaporn P, Sritippayawan S, Aiyasanon N. Comparison of EQ-5D5L, VAS, and SF-6D in Thai Patients on Peritoneal Dialysis. Value Health Reg Issues. 2019;18:59-64. 